\title{
INTRODUKSI BEBERAPA JENIS LEGUMINOSA PERDU DAN PEMBERIAN PUPUK UREA TERHADAP PRODUKSI DAN KUALITAS RUMPUT LAPANGAN
}

\author{
Oktera Seventri $^{1)}$, Sri Mulyani' ${ }^{2}$, dan Fridarti ${ }^{2}{ }^{2}$ \\ 1) Dinas Peternakan dan kesehatan Hewan Kabupaten Solok \\ 2) Fakultas Pertanian Universitas Tamansiswa Padang \\ Email; oktera.seventri@gamail.com, srimulyani60@gamail.com, \\ fridartifridarti69@gmail.com
}

\begin{abstract}
Abstrak
Penelitian ini akan dilaksanakan di Tampat nagari Surian kecamatan Pantai Cermin Kab. Solok dan laboratorium Nutrisi ternak Ruminansia Fakultas Peternakan pada bulan maret sampai bulan Juli 2015. Tujuan Penelitian :Untuk mengetahui pengaruh pemupukan urea dan introduksi legum perdu terhadap produksi dan kualitas rumput lapang. Metode Penelitian: yang digunakan adalah eksperimen dengan Rancangan Acak Lengkap 4 x 4 , yaitu 4 perlakuan dan 4 ulangan. Alasan menggunakan RAL karena lahan padang rumput datar dan perlakuan pada petak yang yang diacak secara penuh. Perlakuan tersebut adalah: $A=$ Rumput lapangan (kontrol), B=Rumput lapangan $+300 \mathrm{~kg} \mathrm{~N} / \mathrm{Ha}$ atau 652,17 kg urea/Ha (.Rekomendasi hasil penelitian Hendarto dan Suwarno (2005) dan Manidol (1992), C=Rumput lapangan introduksi dengan legum Sesbania sesban, D=Rumput lapangan introduksi dengan legum Clotalaria juncea.Hasil Pembahanan: 1. Produksi dan kualitas rumput lapangan dapat ditingkatkan melalui pemupukan dan introduksi dengan leguminosa perdu. 2.Terdapat peningkatan produksi segar rumput lapangan setelah pemupukan urea pada pemotongan pertama (40 hari) sekitar $0,941 \mathrm{~kg} / \mathrm{m}^{2}$ dan produksi BK 0,253 $\mathrm{kg} / \mathrm{m}^{2}$. 3. Peningkatan produksi segar rumput lapangan setelah introduksi dengan legum Sesbania sesban adalah $0,084 \mathrm{~kg} / \mathrm{m} 2$ dan produksi BK 0,032 kg/m2. Sedangkan peningkatan produksi rumput lapangan dengan introduksi legum Clotalaria juncea adalah $0,197 \mathrm{~kg} / \mathrm{m} 2$ dan produksi BK $0,055 \mathrm{~kg} / \mathrm{m} 2$. 4. Terdapat peningkatan kualitas BK rumput lapangan setelah pemupukan dengan urea pada pemotongan pertama (40 hari) adalah 1,974 \% dan kualitas PK 3,214 \%., serta penurunan kandungan SK 0,96\%. Introduksi dengan legum Sesbania sesban dapat meningkan kualitas BK 2,585 \% dan kualitas PK 3,623 \% serta penurunan kandungan SK 1,931\%, sedangkan introduksi dengan legum Clotalaria juncea dapat meningkatkan kualitas BK 1,356 \% dan kualitas PK 3,1\% serta penurunan kandungan SK 3,272\%.
\end{abstract}

Kata Kunci : Rumput Lapangan, introduksi, Leguminosa Perdu 


\section{PENDAHULUAN}

\section{Latar Belakang}

Seiring dengan program pemerintah Indonesia untuk mencapai swasembada ternak sapi dan ruminansia umumnya, maka perlu diusahakan membudidayakan pakan ternak terutama bangsa rumput . Rumput merupakan tanaman "kosmopolit ", bila berada di suatu hamparan yang luas berupa padangan maka disebut padang rumput . Kegunaan dan manfaat suatu padang rumput terhadap ternak sangat tergantung dari nilai gizi padang rumput tersebut, untuk itu padang rumput harus dikelola dengan baik dan teratur agar kebutuhan rumput baik secara kuantitas maupun kwalitas dapat terpenuhi.

Padang rumput di daerah tropis yang ditumbuhi rumput alam/lapangan pada umumnya berproduksi rendah dengan kualitas juga rendah, sehingga tidak cukup untuk memenuhi kebutuhan produksi yang toptimal dari ternak tersebut.

Rumput lapangan ini terdiri dari jenis lokal seperti Axonopus compressus, Paspalum sp, Cynodon dactylon yang sudah menyesuaikan diri dengan kondisi lingkungan, sistem pengembalaan, dan pemotongan yang https://ojs.unitas-pdg.ac.id/embrio/arhcive tidak teratur oleh para petani. Kelemahan rumput jenis lokal ini sebagai sumber makanan ternak adalah produksi bahan kering yang rendah terutama di musim kemarau, kandungan protein kasar dan nilai cernanya cepat menurun serta tidak responsif terhadap pemupukan (Humphrey, 1978). Axonopus compressus yang dipupuk dengan $300 \quad \mathrm{~kg} \quad \mathrm{~N} / \mathrm{Ha}$ dapat menghasilkan 5 ton bahan kering dengan kandungan nitrogen 1 sampai $2 \%$ (Manidol, 1992).

Pemeliharaan ternak ruminansia di Indonesia umumnya masih menerapkan sistem penyediaan pakan dan pemeliharaan ternak secara tradisional dengan sistem potong angkut (cut and carry system) dan terkadang digembalakan di dekat lahan usaha pertanian . Pada musim kemarau ketersediaan rumput maupun hijauan pada umumnya menjadi faktor pembatas dengan kondisi tumbuh yang tidak optimal akibat keterbatasan air. Sebagian besar produksi ternak hanya didukung oleh rumput alam dan tanaman lain yang tumbuh liar. Pada musim hujan pakan ternak hampir sepenuhnya terdiri dari rerumputan alam dan gulma pertanian. Peternak mendapat pakan dari berbagai tempat 
seperti pematang sawah, lahan tidak ditanami, pinggir jalan dan kebun.

Keadaan ini perlu diperbaiki agar diperoleh penyediaan pakan berkualitas baik, melalui perbaikan pada padang rumput sehingga produktivitasnya meningkat.Upaya perbaikan padang rumput alam dapat dilakukan dengan beberapa cara, diantaranya perbaikan manajemen padangan, pembakaran, pemupukan dan introduksi leguminosa (Mc Illroy,1980). Crowder dan Cheda (1982) mengatakan bahwa padang rumput alam umumnya miskin unsur hara akan tetapi dapat ditingkatkan melalui pemupukan $\mathrm{N}, \mathrm{P}, \mathrm{K}, \mathrm{Mg}$, dan $\mathrm{S}$. Selanjutnya Mc Illroy (1977) menyatakan bahwa introduksi jenis-jenis leguminosa dapat meningkatkan kualitas padang rumput alam, karena leguminosa dapat memfiksasi $\mathrm{N}$ udara untuk। kebutuhan sumber $\mathrm{N}$ padangan.

Menurut Mc Ilroy,( 1976) introduksi legum pada padang rumput dapat memberikan pasokan pupuk nitrogen optimal terhadap rumput, tanpa melepaskan sumbangan fiksasi nitrogen dari leguminosa. Leguminosa akan meningkatkan penyediaan protein bagi pengembalaan dan menyediakan nitrogen untuk pertumbuhan rumput. Sanches (1993) menyatakan bahwa peranan legum pada padang rumput adalah memberikan tambahan nitrogen kepada rumput dan memperbaiki kandungan hara secara menyeluruh pada padang pengembalaan, terutama protein, fosfor dan kalsium.

Crotalaria juncea L (Orok-orok) dan Sesbania sesban (Turi) merupakan famili leguminoceae yang dapat digunakan sebagai pupuk organik dengan kandungan $\mathrm{N}$ cukup tinggi. Legum ini dapat dimanfaatkan sebagai pupuk hijau dan menjadi sumber penyedia unsur hara Nitrogen dalam tanah melalui fikssai $\mathrm{N}$ bebas dari udara. Biomassa Crotalaria juncea mengandung $\mathrm{N}$ itrogen $3,01 \%$, sedangkan daun Sesbania sesban mengandung protein $30.1 \%$, serat kasar $5.1 \%$, karbohidrat $42.3 \%$, kedua legum ini juga berpotensi sebagai pakan ternak. (Wildani., 2003 ). Hasil penelitian. Pemupukan yang disertai introduksi legum Centro (Centrosemapubescens) dan Puero (Puerariaphaseoloides) meningkatkan kualitas padangrumput alam dan peningkatan kualitas padangan meliputinya komposisi botani, peningkatan produksi dan kandungan $\mathrm{BK}, \mathrm{BO}, \mathrm{PK}$, serta terjadi peningkatan kecernaan in vitro $\mathrm{BK}, \mathrm{BO}, \mathrm{PK}$ dan 
TDN serta EM. Introduksi legum Puero

(Puerariaphaseoloides) memberikan

hasil lebih baikbila dibandingkan introduksi legum Centro diareal pada rumput alam di Kebar kabupaten Manokwari (Nuhuyanan, 2010).

Perumusan Masalah

1. Apakah rumput lapangan dapat ditingkatkan produksi dan kualitasnya melalui pemupukan urea maupun introduksi dengan leguminosae perdu

2. Berapakah peningkatan produksi dan kualitas rumput lapangan yang di pupuk urea dan di introduksi dengan leguminosae perdu

Tujuan Penelitian : Untuk mengetahui pengaruh pemupukan urea dan introduksi legum perdu terhadap produksi dan kualitas rumput lapang

Manfaat Penelitian

1. Memberi informasi kepada masyarakat khusus petani peternak tentang produksi dan kualitas rumput lapangan yang dipupuk urea dan diintroduksi dengan beberapa jenis legum perdu

2. Mendapatkan pakan ternak khusus rumput yang berkualitas baik dan melindungi tanah/penutup tanah dari hujan serta mengurangi erosi.
3. Secara umum dapat meningkatkan kandungan kualitas tanah (fisik, kimia tanah)

Hipotesis Penelitian: Terdapat peningkatan produksi dan kualitas rumput lapangan yang dipupuk dengan urea dan di introduksi dengan leguminosa.

\section{Materi dan Metode Penelitian}

\section{Materi Penelitian}

Materi penelitian ini menggunakan rumput lapangan, tanaman legum, canavalia ensiformis, lahan dan rumput liar.

\section{Metoda Penelitian}

Penelitian ini merupakan penelitian eksperimen yang menanam tanaman leguminosa pada padang pengembalaan alam yang menggunakan Rancangan Acak Lengkap (RAL).

Perlakuan penanaman tanaman legum :

P1 = Rumput Lapangan (kontrol)

$\mathrm{P} 2$ = Rumput Lapangan introduksi dengan Cloteria juncea

P3 = Rumput Lapangan introduksi dengan Sesbania sesban P4 = Rumput Lapangan + urea Model matematika dan rancangan yang digunakan dalam penelitian ini 
berdasarkan Steel dan Torrie (1991)

adalah : $\quad \mathbf{Y}_{\mathbf{i j}}=\boldsymbol{\mu}+\boldsymbol{\tau}_{\mathbf{i}}+\boldsymbol{\varepsilon}_{\mathbf{i j}}$

Keterangan :

$\mathbf{Y}_{\mathbf{i j}}=$ Nilai pengamatan dengan perlakuan ke $\mathrm{i}$ dan ulangan ke $\mathrm{j}$

$\boldsymbol{\mu}=$ Nilai tengah umum

$\boldsymbol{\tau}_{\mathbf{i}}=$ Pengaruh perlakuan ke $\mathrm{i}$

$\boldsymbol{\varepsilon}_{\mathbf{i j}}=$ =Pengaruh sisa (acak) ke-j yang mendapat perlakuan ke-i

i $=$ Perlakuan $(1,2,3,4)$

j = Ulangan $(1,2,3,4)$

Peubah yang diamati dalam penelitian ini adalah :

1. Kandungan protein kasar rumput lapangan

2. Kandungan serat kasar rumput lapangan

3. Produksi segar bahan kering rumput lapangan
4. Kandungan protein bahan kering rumput lapangan

\section{Persiapan dan Pelaksanaan Penelitian}

1. Disiapkan lahan yang ditumbuhi rumput lapangan 3 petak dengan ukuran $3 \times 5$

2. Jarak antar petak $1 \mathrm{~m}$

3. Meratakan pertumbuhan rumput lapangan dengan jarak permukaan tanah permukaan tanah $15 \mathrm{~cm}$

4. Dalam masing-masing petak ditanami aneka legum, sesuai perlakuan dengan jarak $20 \mathrm{~cm}$

5. Menjelang legum tumbuh disiangi 1x sehari

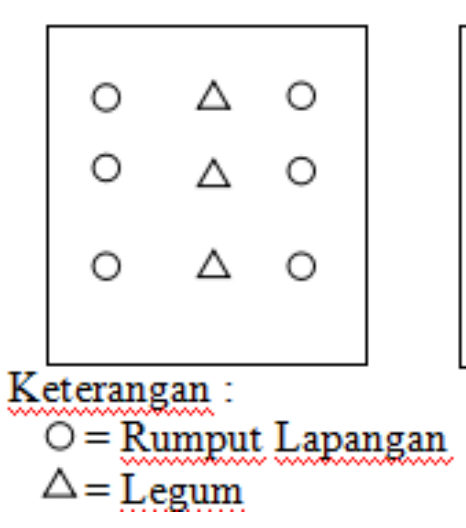

\section{Pengamatan}

1. Setelah umur 40 hari dilakukan pemotongan rumput. Masing-masing petak sebanyak \pm 5 cuplikan dengan berat $500 \mathrm{~g}$.

2. Timbang berat segar setelah sampel kering angin- 
anginkan menjelang dibawa

kelabor.

3. Selanjutnya

dilakukan analisa kandungan zat makanan dilaboratorium

\section{Analisis Data}

Data yang diperoleh dianalisis secara statistik menggunakan analisis keragaman dengan Rancangan Acak Kelompok (RAK). Jika terdapat perbedaan antara perlakuan yang nyata maka diuji dengan DMRT (Duncan's New Multiple Range Test).

\section{HASIL DAN PEMBAHASAN}

\section{Rataan Produksi Segar Rumput}

\section{Lapangan}

Berdasarkan data hasil penelitian, pada Tabel 1 dapat dilihat rataan produksi segar rumput lapangan dengan penambahan pupuk urea dan introduksi beberapa jenis legum perdu (Clotalaria juncea dan Sesbania sesban).
Rataan produksi segar rumput lapangan tertinggi terdapat pada perlakuan B (pupuk urea) yaitu 1,298 $\mathrm{kg} / \mathrm{m}^{2}$ diikuti dengan introduksi legum perlakuan D ( Clotalaria juncea) yaitu 0,554 kg/m², dan perlakuan C ( Sesbania sesban ) yaitu $0,441 \mathrm{~kg} / \mathrm{m} 2$ dan terendah perlakuan A ( Rumput kontrol ) yaitu $0,357 \mathrm{~kg} / \mathrm{m}^{2}$. Analisis ragam menunjukkan bahwa perlakuan memberikan pengaruh yang berbeda sangat nyata $(\mathrm{P}<0.01)$ terhadap produksi segar rumput lapangan. Hal ini disebabkan kemampuan tanah dalam menyediakan unsur hara terutama Nitrogen berbeda-beda untuk masing masing perlakuan. Pemberian pupuk urea (perlakuan B) memperlihatkan pertambahan tinggi rumput lapangan secara signifikan, akibat penyerapan nitrogen yang berkemungkinan lebih banyak dan sempurna sehingga tanahnya lebih subur dibandingkan perlakuan lainnya. Menurut Supardi (1983) kesuburan tanah adalah kemampuan tanah dalam menyediakan

Tabel 1. Rataan Produksi Segar Rumput Lapangan $\left(\mathrm{kg} / \mathrm{m}^{2}\right)$

\begin{tabular}{|c|c|c|c|c|c|c|}
\hline \multirow[t]{2}{*}{ Perlakuan } & \multicolumn{4}{|c|}{ Ulangan } & \multirow[t]{2}{*}{ Jumlah } & \multirow[t]{2}{*}{ Rataan } \\
\hline & 1 & 2 & 3 & 4 & & \\
\hline $\mathrm{A}(\mathrm{R} L)$ & 0,382 & 0,287 & 0,385 & 0,374 & 1,431 & $0,357^{c}$ \\
\hline $\mathrm{B}(\mathrm{RL}+\mathrm{Ure})$ & 1,475 & 1,318 & 1,341 & 1,059 & 5,194 & $1,298^{b}$ \\
\hline $\mathrm{C}(\mathrm{RL}+\mathrm{S} . \mathrm{s})$ & 0,442 & 0,424 & 0,461 & 0,438 & 1,767 & $0,441^{\mathrm{a}}$ \\
\hline $\mathrm{D}(\mathrm{RL}+\mathrm{C} . \mathrm{j})$ & 0,532 & 0,500 & 0,563 & 0,621 & 2,217 & $0,554^{\mathrm{a}}$ \\
\hline \multicolumn{6}{|c|}{$\mathrm{SE}$} & 0,066 \\
\hline
\end{tabular}


Tabel 2. Rataan Produksi Bahan Kering Rumput Lapangan $\left(\mathrm{kg} / \mathrm{m}^{2}\right)$

\begin{tabular}{|c|c|c|c|c|c|c|}
\hline \multirow[t]{2}{*}{ Perlakuan } & \multicolumn{4}{|c|}{ Ulangan } & \multirow[t]{2}{*}{ Jumlah } & \multirow[t]{2}{*}{ Rataan } \\
\hline & 1 & 2 & 3 & 4 & & \\
\hline $\mathrm{A}(\mathrm{RL})$ & 0,092 & 0,069 & 0,092 & 0,090 & 0,345 & $0,086^{\mathrm{a}}$ \\
\hline $\mathrm{B}(\mathrm{RL}+\mathrm{Ure})$ & 0,384 & 0,345 & 0,350 & 0,276 & 1,357 & $0,339^{b}$ \\
\hline $\mathrm{C}(\mathrm{RL}+\mathrm{S} . \mathrm{s})$ & 0,117 & 0,113 & 0,123 & 0,118 & 0,472 & $0,118^{\mathrm{a}}$ \\
\hline $\bar{D}(\mathrm{RL}+\mathrm{C} . \mathrm{j})$ & 0,135 & 0,127 & 0,144 & 0,159 & 0,566 & $0,141^{\mathrm{a}}$ \\
\hline \multicolumn{6}{|c|}{$\mathrm{SE}$} & 0,017 \\
\hline
\end{tabular}

Keterangan: Superskrip yang berbeda pada kolom yang sama menunjukkan perbedaan sangat nyata $(\mathrm{P}<0.01)$

$\mathrm{SE}=$ Standar Error

unsur hara dalam jumlah cukup dan seimbang bagi pertumbuhan suatu tanaman disamping faktor lain air dan cahaya. Kesuburan tanah sangat menentukan pertumbuhan rumput, tanah yang menyediakan unsur hara cukup dan berimbang akan menghasilkan produksi daun yang optimal. Purwowidodo (1992) menyatakan bahwa pemberian pupuk nitrogen akan dapat meningkatkan pertumbuhan batang dan tinggi tanaman, disamping itu juga dapat merangsang pertumbuhan anakan. Hasil uji DMRT menunjukkan bahwa produksi segar rumput lapangan pada perlakuan B (pemberian urea) berbeda sangat nyata $(\mathrm{P}<0.01)$ lebih tinggi dibandingkan perlakuan lainnya ( A, C dan D) sedangkan introduksi masingmasing legum perdu (perlakuan $\mathrm{C}$ dan D) berbeda tidak nyata $(\mathrm{P}>0.05)$ terhadap produksi segar rumput lapangan, namun secara angka lebih tinggi menghasilkan produksi segar dari rumput kontrol (perlakuan A) Berbeda tidak nyatanya produksi rumput segar dari masing-masing perlakuan introduksi legum disebabkan pada perlakuan tersebut yang dihitung hanya produksi rumput tanpa legum, disamping itu kemungkinan suplai Nitrogen dari legum pada pemotongan pertama ini belum optimal, tetapi produksi segarnya masih tinggi bila dibandingkan rumput kontrol. Reksohadiprodjo (1985) menyatakan bahwa produksi hijauan pada pertanaman polikultur lebih tinggi dibandingkan hanya monokultur dan peranan leguminosa dapat mensubstitusi penggunaan pupuk nitrogen.

2 Rataan Produksi Bahan kering Rumput Lapangan 
Hasil Penelitian ratan produksi di lihat pada tabel 2.

Bahan kering Rumput Lapangan dapat

Tabel 2. Menunjukkan rataan produksi Nitrogennya hampir sama berkisar

Tabel 3. Rataan Kandungan BK Rumput Lapangan (\%)

\begin{tabular}{|c|c|c|c|c|c|c|}
\hline \multirow[t]{2}{*}{ Perlakuan } & \multicolumn{4}{|c|}{ Ulangan } & \multirow[t]{2}{*}{ Jumlah } & \multirow[t]{2}{*}{ Rataan } \\
\hline & 1 & 2 & 3 & 4 & & \\
\hline$A(R L)$ & 24,190 & 24,112 & 24,095 & 24,241 & 96,639 & $24,160^{d}$ \\
\hline $\mathrm{C}(\mathrm{RL}+\mathrm{Ure})$ & 26,043 & 26,225 & 26,141 & 26,125 & 104,535 & $26,134^{b}$ \\
\hline $\mathrm{B}(\mathrm{RL}+\mathrm{S} . \mathrm{s})$ & 26,487 & 26,705 & 26,741 & 27,047 & 106,982 & $26,745^{\mathrm{a}}$ \\
\hline $\mathrm{A}(\mathrm{RL}+\mathrm{C} . \mathrm{j})$ & 25,432 & 25,357 & 25,568 & 25,705 & 102,064 & $25,516^{\mathrm{a}}$ \\
\hline \multicolumn{5}{|c|}{$\mathrm{SE}$} & & 0,104 \\
\hline
\end{tabular}

Keterangan: Superskrip yang berbeda pada kolom yang sama menunjukkan perbedaan sangat nyata $(\mathrm{P}<0.01)$

$\mathrm{SE}=\mathrm{Standar}$ Error

bahan kering rumput lapangan masingmasing perlakuan, yang tertinggi pada perlakuan $\mathrm{B}$ (pemberian pupuk urea) yaitu $0,3393 \mathrm{~kg} / \mathrm{m}^{2}$ yang terendah pada perlakuan A (rumput kontrol) yaitu $0,0864 \mathrm{~kg} / \mathrm{m}^{2}$. Analisis ragam (Lampiran 3) menunjukkan bahwa perlakuan memberikan pengaruh yang berbeda sangat nyata $(\mathrm{P}<0.01)$ terhadap produksi bahan kering (BK) rumput lapangan. Hasil uji DMRT menunjukkan pada perlakuan B (pupuk urea) berbeda sangat nyata $(\mathrm{P}<0.01) \quad$ lebih tinggi dibandingkan perlakuan A,C dan D terhadap produksi BK rumput lapangan. Produksi BK rumput lapangan pada perlakuan D berpengaruh nyata $(\mathrm{P}<0.05)$ dengan perlakuan C. Bila dibandingkan kedua perlakuan tersebut , sama-sama menggunakan introduksi legum dengan yang kandungan antara $3-5 \%, \quad$ sehingga memperlihatkan produski segar berbeda tidak nyata, tetapi produksi BK berpengaruh nyata dengan hanya perbedaan angka $0,02 \mathrm{~kg} / \mathrm{m}^{2}$. Hal ini berkemungkinan besar juga disebabkan suplai kandungan Nitrogen dengan kisaran tersebut belum dimanfaatkan secara sempurna oleh masing-masing tanaman rumput perlakuan. Havlin et al ., (1999) menyatakan pemupukan dengan nitrogen akan meningkatkan jumlah daun dan memperluas helai daun. Meningkatnya jumlah dan luas daun menyebabkan peningkatan proses fotosintesa sehingga pertumbuhan vegetatif tanaman seperti daun anakan, batang bertambah sehingga produksi berat kering total tanaman juga mengalami peningkatan. Rosmarkam dan Yuwono (2002) menyatakan 
pemupukan dengan nitrogen akan dapat meningkatan produksi dan berat kering total tanaman.

\section{Rataan Kandungan Bahan Kering Rumput Lapangan}

Tabel 3. Menunjukkan rataan kandungan BK rumput lapangan masing-masing perlakuan , yang tertinggi terdapat pada perlakuan introduksi legum Sesbania sesban (perlakuan C) yaitu 26, $745 \%$, diikuti dengan perlakuan A dan D yaitu 26, 134 $\%$ dan $25,516 \%$ sedangkan rumput kontrol 24,160\%.

Analisis ragam menunjukkan bahwa setiap perlakuan memberikan pengaruh yang berbeda sangat nnyata $(\mathrm{P}<0.01)$ terhadap kandungan BK rumput lapangan. Hasil uji DMRT menunjukkan bahwa perlakuan C (legum Sesbania) berbeda sangat nyata $(\mathrm{P}<0.01)$ lebih tinggi dari perlakuan $\mathrm{A}, \mathrm{B}$ dan $\mathrm{D}$ terhadap kandungan BK rumput lapangan.Berbeda sangat nyatanya perlakuan $\mathrm{C}$ dengan perlakuan $\mathrm{D}$ (legum Clotalaria) terhadap kandungan BK, disebabkan rumput yang diintroduksi legum Sesban memperlihat proporsi pertumbuhan batang le bih banyak dibandingkan rumput yang dintroduksi dengan legum Clotalaria, sedangkan Clotalaria tumbuh lebih menutupi tanah dengan proporsi daun yang lebih banyak. Oleh karena itu pada perlakuan C (legum Sesban) dengan proporsi batang yang lebih tinggi mengakibatkan kandungan BK juga menjadi tinggi. Bila proporsi daun lebih tinggi dari batang, maka kandungan BK lebih rendah, hal ini disebabkan karena daun mengandung air yang lebih banyak dibandingkan batang sehingga akan berpengaruh terhadap kandungan BK.

Rumput lapangan sebagai bahan pakan terdiri dari air dan bahan kering, bila bahan kandungan air tinggi maka bahan kering akan rendah dan sebaliknya. Pada daun terdapat kandungan karbohidrat non struktural lebih dominan dan sebaliknya pada batang maupun cabang lebih dominan terdapat karbohidrat struktural . Hasil penelitian Nuhuyaman menyatakan bahwa pemupukan menggunakan kombinasi pupuk NPK,TSP dan $\mathrm{K}_{2} \mathrm{O}$ dan introduksi legum Centro dan Peuro pada rumput lapangan di Kebar Papua Barat, tidak memberikan pengaruh dalam peningkatan kualitas $\mathrm{BK}$, tetapi 
memberikan peningkatan kualitas $\mathrm{BO}$ dan PK

\section{Rataan Kandungan Protein Kasar.}

Pada Tabel 4 dapat dilihat rataan kandungan PK rumput lapangan dengan penambahan pupuk urea dan introduksi dengan legum Clotalaria juncea dan Sesbania sesban, diperoleh kandungan PK tertinggi pada perlakuan C yaitu 10,027 \% dan yang terendah perlakuan A yaitu $6,404 \%$.

Analisis ragam menunjukkan bahwa penambahan urea dan introduksi legum perdu pada rumput lapangan memberikan pengaruh yang berbeda sangat nyata $(\mathrm{P}<0.01)$ lebih tinggi dibandingkan kandungan PK rumput kontrol. Penambahan pupuk urea pada rumput dapat meningkatkan kandungan protein rumput melalui serapan akar dalam bentuk nitrat, sehingga meningkatkan pertumbuhan vegetatif rumput seperti jumlah daun lebih banyak yang menandakan peningkatan kualitas hijauan rumput. Peningkatan kandungan PK seiring dengan penurunan kandungan SK rumput. Introduksi legum pada padang rumput, juga merupakan suplai $\mathrm{N}$ dari fiksasi bakteri Rhizobium ke dalam tanah dan secara tak langsung juga meningkatkan kandungan PK rumput. Disamping itu

Tabel 4. Rataan Kandungan PK Rumput Lapangan (\%)

\begin{tabular}{|c|c|c|c|c|c|c|}
\hline \multirow[t]{2}{*}{ Perlakuan } & \multicolumn{4}{|c|}{ Ulangan } & \multirow[t]{2}{*}{ Jumlah } & \multirow[t]{2}{*}{ Rataan } \\
\hline & 1 & 2 & 3 & 4 & & \\
\hline $\mathrm{A}(\mathrm{R} \mathrm{L})$ & 6,243 & 6,643 & 6,384 & 6,347 & 25,619 & $6,404^{b}$ \\
\hline $\mathrm{B}$ (RL+Urea) & 9,867 & 9,704 & 9,783 & 9,118 & 38,474 & $9,618^{c}$ \\
\hline $\mathrm{C}(\mathrm{RL}+\mathrm{S} . \mathrm{s})$ & 10,585 & 9,278 & 10,704 & 9,542 & 40,110 & $10,027^{\mathrm{a}}$ \\
\hline $\mathrm{D}(\mathrm{RL}+\mathrm{C} . \mathrm{j})$ & 9,036 & 9,781 & 9,096 & 10,103 & 38,017 & $9,504^{\mathrm{a}}$ \\
\hline SE & & & & & & 0.342 \\
\hline
\end{tabular}

Keterangan: Superskrip yang berbeda pada kolom yang sama menunjukkan perbedaan sangat nyata $(\mathrm{P}<0.01)$

$$
\mathrm{SE}=\text { Standar Error }
$$

sangat nyata $\quad(\mathrm{P}<0.01) \quad$ terhadap kandungan PK rumput lapangan. Hasil Uji DMRT menunjukkan introduksi legum Sesbania sesban, Clotalaria juncea dan penambahan urea berbeda nitrogenyang tersedia bagi tanaman yang prosesnya dalam tanaman sangat dipengaruhi oleh jumlah pelarut substrat yang tersedia. Pemberian urea dan 
Tabel 5. Rataan Kandungan SK Rumput Lapangan (\%)

\begin{tabular}{|l|l|l|l|l|l|l|}
\hline \multirow{2}{*}{ Perlakuan } & \multicolumn{4}{|l|}{ Ulangan } & Jumlah & Rataan \\
\cline { 2 - 5 } & 1 & 2 & 3 & 4 & & \\
\hline A(RL) & 27,285 & 27,185 & 27,088 & 27,451 & 109,009 & $27,252^{\text {a }}$ \\
\hline B(RL+Urea) & 26,323 & 26,425 & 26,182 & 26,232 & 105,168 & $26,292^{\text {b }}$ \\
\hline C(RL+S.s) & 25,035 & 25,234 & 25,490 & 25,523 & 101,283 & $25,321^{\text {c }}$ \\
\hline D(RL+C.j) & 23,945 & 23,873 & 24,141 & 23,960 & 95,920 & $23,980^{\text {d }}$ \\
\hline SE
\end{tabular}

Keterangan: Superskrip yang berbeda pada kolom yang sama menunjukkan perbedaan sangat nyata $(\mathrm{P}<0.01)$

\section{$\mathrm{SE}=$ Standar Error}

penggunaan legum dapat meningkatkan kadar $\mathrm{N}$ total $\mathrm{dlm}$ tanah, hal ini disebabkan pupuk yang diberikan mengandung $\mathrm{N}$, walaupun faktor kehilangan $\mathrm{N}$ pada tanah alkalis dan iklim kering cukup besar tetapi pemberian pupuk $\mathrm{N}$ dapat meningkatkan $\mathrm{N}$ total dalam tanah. (Susetyo et al., 1993). Menurut Rao et al (1977) nitrogen yang ada dalam tanah diserap oleh akar rumput, yang sebagain besar nitrogen ini dalam bentuk nitrat. Nitrat di dalam tubuh tanaman segera diubah menjadi nitrit oleh enzim nitrat reduktase. Enzim ini bersufat indusibel, artinya kegiatan akan menigkat dengan meningkatnya sumber nitrat. Nitrat reduktase merupakan enzim yang diperlukan pada langkah pertama reduktase nitrat atau sintesis protein. Respon perlakuan pemupukan $\mathrm{N}$ terhadap kandungan protein kasar rumput pakan adalah konstan hal ini terjadi karena laju sintesis protein dipengaruhi oleh aktivitas nitrat reduktase pada tumbuhan yang menyerap $\mathrm{NO}_{3}$, sebagai sumber nitrogen utama (Salisbury dan Ross, 1995), diketahui aktivitas nitrat reduktase rumput pakan secara umum konstan.Pemupukan urea akan meningkatkan keterersediaan nitrogen dalam tanah. Nitrogen dalam tanah merupakan hasil katalis dari urea. Urea akan dihidrolisis menjadi amonium karbonat oleh enzim urease. Amonium karbonat dengan adanya air terdisosiasi menjadi ion amonium dan karbonat yang dapat diserap oleh tanaman (Sanchez, 1992).

\section{Rataan Kandungan Serat Kasar}

Pada 5 dapat diketahui rataan SK rumput lapangan yang tertinggi pada perlakuan A ( 27,252\%) yaitu rumput kontrol, sedangkan yang terendah 
adalah pada perlakuan D ( 23,980\%) yaitu introduksi legum Clotalaria juncea dan dikuti oleh perlakuan B $(25,321 \%)$ yaitu imtroduksi legum Sesbania sesban serta perlakuan C $(26,292 \%)$ yaitu pemupukan dengan urea.

Analisis ragam menunjukkan bahwa perlakuan memberikan pengaruh yang berbeda sangat nyata $(\mathrm{P}<0.01)$ terhadap kandungan SK rumput lapangan. Hasil uji DMRT menunjukkan bahwa perlakuan $\mathrm{D}$ berbeda sangat nyata $(\mathrm{P}<0.01)$ lebih rendah dibandingkan perlakuan lainnya terhadap kandungan SK rumput lapangan. Hal ini perlakuan introduksi legum dan pemupukan dengan urea sangat signifikan terhadap penurunan kandungan SK rumput lapangan dibandingkan yang tidak diintroduksi legum maupun dipupuk urea. Hal ini sejalan dengan peningkatan kandungan PK rumput lapangan yang semakin meningkat bila dilakukan introduksi legum maupun pemupukan urea atau nitrogen. Perlakuan D (introduksi legum Clotalaria) sangat nyata $(\mathrm{P}<0.01)$ lebih rendah kandungan SK nya dibandingkan perlakuan C (introduksi legum Sesbania). Hal ini berhubungan dengan kualitas BK yang terdapat pada masing- masing perlakuan tersebut. Bahan kering yang terdapat pada perlakuan D lebih rendah dibandingkan perlakuan $\mathrm{A}, \mathrm{B}$ dan $\mathrm{C}$, yang berbanding lurus dengan kandungan SK, karena SK dan PK berada dalam bahan kering. Kandungan SK akan selalu berbanding terbalik dengan kandungan PK suatu bahan pakan termasuk hijauan. Kadar SK pada tanaman/ hijauan disebabkan terjadinya peningkatan bobot dinding sel dan menurunnya isi sel tanaman. Dinding sel lebih banyak disusun oleh selulosa dan hemiselulosa. Pemupukan nitrogen akan menurunkan kadar serat kasar pada rumput P.maximum dan M. Artropurpureum sedangkan pemupukan belerang hanya menurunkan SK pada $\mathrm{P}$ Maximum saja. Hal ini menunjukkan pemupukan nitrogen maupun belerang meningkatkan kualitas dan seiring dengan menurunnya kadar serat kasar (Purnomo,J dkk., 2004)

\section{KESIMPULAN}

Berdasarkan hasil penelitian dapat disimpulkan bahwa :

1. Produksi dan kualitas rumput lapangan dapat ditingkatkan melalui 
pemupukan dan introduksi dengan leguminosa perdu.

2.Terdapat peningkatan produksi segar rumput lapangan setelah pemupukan urea pada pemotongan pertama (40 hari) sekitar 0,941 $\mathrm{kg} / \mathrm{m}^{2}$ dan produksi $\mathrm{BK} 0,253$ $\mathrm{kg} / \mathrm{m} 2$

3. Peningkatan produksi segar rumput lapangan setelah introduksi dengan legum Sesbania sesban adalah $0,084 \mathrm{~kg} / \mathrm{m} 2$ dan produksi $\mathrm{BK}$ $0,032 \mathrm{~kg} / \mathrm{m} 2$. Sedangkan peningkatan produksi rumput lapangan dengan introduksi legum Clotalaria juncea adalah 0,197 $\mathrm{kg} / \mathrm{m} 2$ dan produksi BK 0,055 $\mathrm{kg} / \mathrm{m} 2$.

4. Terdapat peningkatan kualitas BK rumput lapangan setelah pemupukan dengan urea pada pemotongan pertama (40 hari) adalah $1,974 \%$ dan kualitas PK $3,214 \%$. serta penurunan kandungan SK 0,96 \%. Introduksi dengan legum Sesbania sesban dapat meningkan kualitas BK $2,585 \%$ dan kualitas PK 3,623\% serta penurunan kandungan SK $1,931 \%$, sedangkan introduksi dengan legum Clotalaria juncea dapat meningkatkan kualitas BK
1,356 \% dan kualitas PK 3,1\% serta penurunan kandungan SK $3,272 \%$.

\section{DAFTAR PUSTAKA}

Bahar, S dan A Prabowo 1994. Status hara padang rumput alam di Tanete Riaja, Kan Barau Sulsel Seminar Nasional Sains dan Teknologi Peternakn. Pengolahan Dan Komunikasi Hasil-hasil Penelitian. Balai Penelitian Ternak-Puslitbangnak .hlm 297299

Dewi, S,R.E. 2009 . Respon Tan Rumput pakan ternak Poliploid dan Diploid yang toleran tanah sa;in terhadap pemupukan niytogen berdasarkan serapan $\mathrm{n}$ aktivitasNitrat reduktase dan kualitas hijauan. Jur Biologi IKIP PGRISemarang. Proseding Seminar Nasional Biologi : Inovasi Biologu dan Pendidikan Biologi dalam Penegmbanagn sumber daya manusia. Juli 2009.

Havlin, J.L., Beaton, J.D., Tisdale, S.L., Nelson, W.L 1999. Soil Fertility and Fertilizer. Prentice Hall Upper Saddle River. New Yersey

Hendratno,C.dkk. 1987. Penelitian dan Pengembangan Teknologi Molases Blok. Lokakarya Pelaksanaan Iji coba Molases Blok di Ciawi, Bogor.

Jalaluddin, S. 1982. Peranan Rumput Kultur Sebagai Makanan Ternak Sapi di Sumatera Barat.Laporan Penelitian Fakultas Peternakan Universitas Andalas Padang. 
Mc.ilroy.R.J.1977.Pengantar Budidaya Padang

RumputTropik.Terjemahan Prodya Paramita.Jakarta.

Noviastuti, ET. 2006. Pengaruh Jarak Tanam dan Jumlah Tanaman Per Lubang Tanam Pada Pertumbuhan dan Hasil Tanaman Otok-orok. Skripsi Universitas Brawijaya Malang. pp 24

Nuhuyanan,1..E 2010. Pengaruh Pemupukan dan Introduksi Legum terhadap Kualitas Padang Rumput Alam Di Kebar Kabupaten Manokwari Jurnal Ilmu Peternakan,Vol. 5 No. 1 hal. 13 19

Osmarkam. A,. Yuwono, N. W. 2002. Ilmu Kesuran Tanah Yogjakarta: Penerbit Kanisius

Purnomo.J. Tuherkih,E. Wigena,P.I.G. E. Sutedi. 2004. Pengaruh Pemupukan Nitrogen dan Belerang Terhadap Produksi dan Kualitas Tanaman Pakan Di Sumbawa, Nusa Tenggara barat. Seminar Nasional Teknologi Peternakan dan Veteriner. BPT. Bogor

Purwowidodo. 1992. Telaah Kesuburan Tanah. Bandung. Penerbit Angkasa

Reksohadiprojo.S 1996. Kualitas dan produktivitas hijauan pakan diIndonesia. Makalah Seminar Nasional Hiajuan Pakan. Bogor. 16 Januari 1996

Reksohadiprodjo. S, 1994. Produksi Tanaman Hijauan Makanan Ternak Tropik. Cetakan Pertama.Edisi ketiga.BPEF. Yogyakarta.
Reksohadiprojo, S. 1985. Produksi Tanaman Hijauan Makanan ternak.Ed.Pertama. BPPE Yogyakarta.

Sanchez, P. 1976. Propertis and management of Soil In The Tropics. New York; A WilleyIntersience Publication

Soedomo, R. 1985. Produksi Hijauan Makanan Ternak Tropik. Yogyakarta: Badan Penerbitan Fakultas Ekonomi Universitas Gajah mada.

Susetyo,S.L.,Kismono,B.Suwardi, Soedarmadi, A.Parakkasi dan S.L Suwoko. 1973. Laporan Survey potensi padang pengembalaan alam di beberapa kab. Propinsi Sulsel Fak,Peternakan IPB. Tidak dipublikasi.kan

Steel, R. G. dan J. H. Torrie. 1991. Prinsip dan Prosedur Statistika Suatu Pendekatan Biometrik. Ed2Cet 2. Alih Bahasa oleh Bambang Sumantri. Gramedia Pustaka Utama. Jakarta.

Sutejo M.M. 2002. Pupuk Dan Cara Pemupukan PT Rieka Cipta Jakarta. Pp177

Soesetyo, S. 1980. Padang Penggembalaan. Departemen Ilmu Makanan Ternak. Fakultas Peternakan IPB. Bogor.

Suntoro. WS. 2009. Tanaman Orok-orok (Clotalaria juncea) Cocok Sebagai Pupuk Hijau (suntoro.staff.uns,ac.id/ 2009/04/23 tanaman orok-orok) 
Wildani. A. 2003. Manfaat Tanaman Turi Dan Orok-orok. Blogspot. 20 Feb 2003 